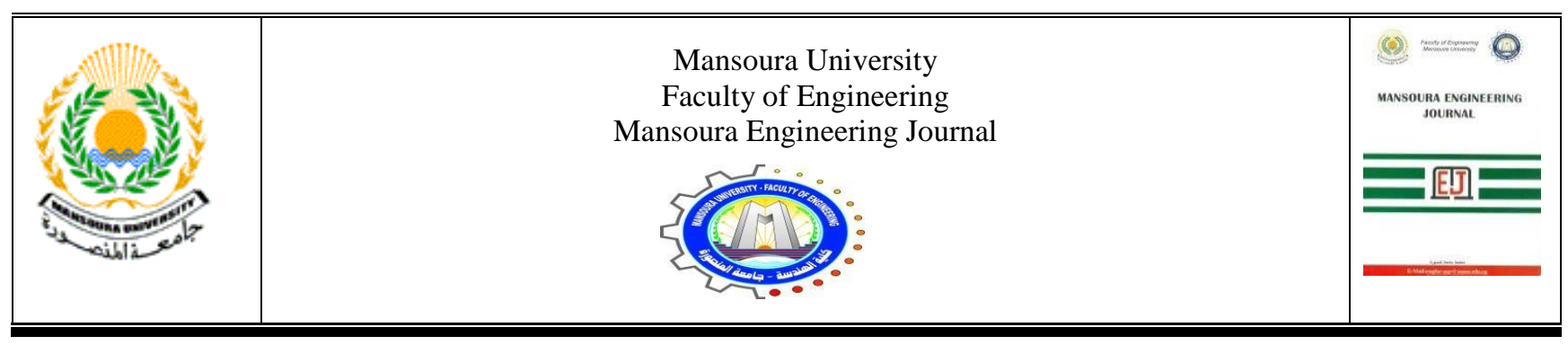

\title{
Comparative Experimental Study of Low GWP Alternative for R134a in a Walk-in Cold Room
}

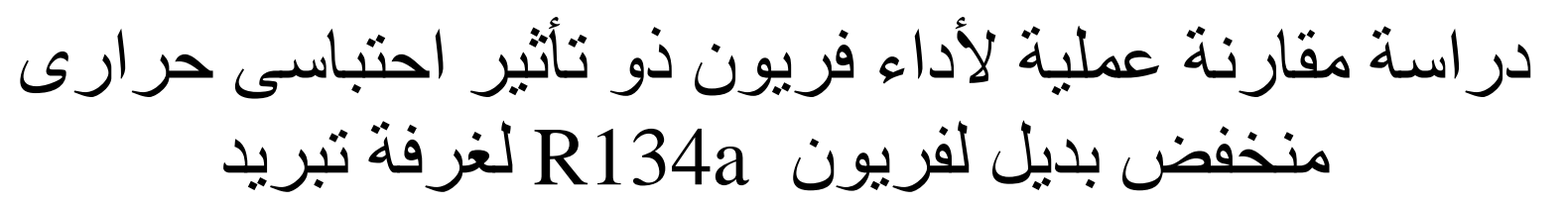

\author{
A. Khalil", A.E. Kabeel", M.M. Bassuoni" and M.S.Raslan" \\ *Tanta University, Faculty of Engineering, Mechanical Power Dept., Egypt.
}

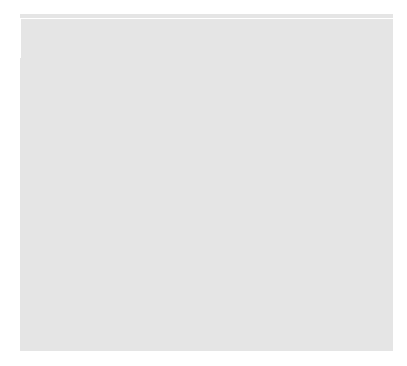

\begin{tabular}{|c|}
\hline i \\
\hline
\end{tabular}

Abstract: - The environmental problems induced by the ongoing increase in the global worming potential (GWP) pose a significant interest among researchers. It was found that, the currently used refrigerants are with high GWP [1], so that $\mathrm{t}$ becomes necessary to search for alternatives to these refrigerants that can properly operate on the same systems but with low GWP. Therefore a walk-in cold room working with vapor compression cycle is constructed to compare the performance of the high GWP refrigerant R134a to low GWP refrigerant R1234ze in a trail to provide a solution to the problem of high GWP of refrigerants currently used in cold rooms. The results obtained in this study have shown that, the cooling capacity of R1234ze was lower than that of R134a by $2 \%$ to $13 \%$. The lowest evaporating temperature that could be reached for $\mathrm{R} 1234 \mathrm{ze}$ is $-13{ }^{\circ} \mathrm{C}$ while the lowest temperature of $\mathrm{R} 134 \mathrm{a}$ is $-30^{\circ} \mathrm{C}$. Regarding the power consumption, R1234ze has lower power consumption than R134a by about $9 \%$ to $15 \%$ therefore it can be concluded that $R$ 1234ze can be recommended to be used at high and medium evaporating temperature after carrying out the modification on the refrigeration cycle

\section{INTRODUCTION}

he continuous growth in GWP all over the world constitutes a threatening environmental phenomenon that should be studied to find scientifically based solutions. Refrigerants used in the last few decades such as CFCs and HCFCs including R11, R12, R22 and R502 have depleted the ozone layer and consequently lead to the greenhouse effect on the climate. Therefore, the use of low GWP and zero ozone depletion potential (ODP) refrigerants becomes very essential to prevent further depletion of the ozone layer and consequently guard against the greenhouse effect on climate. In the year 1996 the production of R11 and R12 were completely banned, furthermore the production of HCFCs will be completely banned after 2030. Although the ODP of R134a and R404a are zero however, they have a high value of GWP. The production of $\mathrm{R} 134 \mathrm{a}$ may thus be completely 
forbidden in the near future as it was restrained in the Tokyo Protocols signed in 1997 and Montreal Protocol $[2,3]$.

As a result, efforts are made in order to find out alternative refrigerants to replace the currently used high GWP refrigerants withR1234yf and R1234ze (E). R1234ze (E) will be referred simply as R1234ze. They have been proposed as alternative refrigerants for R134a, which has a GWP of 1430. Both of these refrigerants have zero ODP and a GWP value for R1234ze is 6 and for R1234yf is 4, with mild flammability and low toxicity [4-8].

In a simulation model for the steady-state analysis of domestic refrigerator-freezer validated by experimental data, it was found that, for R1234ze the evaporator capacity decreased about $21.5 \%$ and the COP increased about $7.9 \%$ [9]. A comparative study on a system using an expander as a configuration on an internal heat exchanger on system using R1234yf, R1234ze and R134a as a working fluid, an increment of $9 \%$ to $15 \%$ for R1234yf and $11 \%$ to $20 \%$ for R1234ze on COP with respect to basic cycle was recorded. However, the main disadvantage of these refrigerants on the system was the increase in complexity of the system and increase of cost [10]. A comparative performance analysis of low GWP refrigerants R1234yf, R1234zeand R600a inside a commercial roll-bond evaporator for household refrigerators recorded that, vaporization performances for R1234ze, R1234yf and HC600a were similar to that of R134a at evaporation temperatures, $15^{\circ} \mathrm{C}$ and $-20{ }^{\circ} \mathrm{C}$. [11]. Internal heat exchanger (IHX) affects positively the performance of vapor compression system. By using R1234ze and R450A (R134a/R1234ze commercial mixture) as replacements for $\mathrm{R} 134 \mathrm{a}$ at evaporation temperatures $260 \mathrm{~K}, 270 \mathrm{~K}$ and $280 \mathrm{~K}$ and condensation temperatures $300 \mathrm{~K}, 310 \mathrm{~K}$ and $330 \mathrm{~K}$, the cooling capacity increases with high compression ratios particularly for R1234ze. R134a has greater refrigeration effect and refrigerant mass flow rate. COP for R1234ze and R450A increases using IHX. [12]

As drop-in replacement in a screw chiller with 200 TR using R134a with R1234ze and D4Y a test was carried out by [13], recording low cooling capacity for R1234ze about $22.6 \%$ with about $5.5 \%$ increase in COP. D4Y has shown nearly the same capacity as R134a and decrease in COP about 2.6\%. To evaluate energy consumption, an experiment was conducted to assess and compare the performance of R134a to that of R1234yf and R1234ze, using AHAM standard HRF-1 [14], these refrigerants were tested as drop-in replacements, with no performance enhancing modifications to the refrigerators. It was found that, R1234yf has higher energy consumption than R-134a and R1234ze had lower energy consumption than R-134a. The results presented in [15] recommended that, in order to replace R-134a with R$1234 \mathrm{ze}$ in domestic refrigerators, the lower capacity would need to be addressed.

In the present study, experimental performance comparison between refrigerants R1234ze and R134a are carried out. A walk-in cold room was constructed that uses a vapor compression cycle for the two refrigerants as a working fluid, in order to study and evaluate the performance of a low GWP alternative refrigerant for R134a. The results are compared with published work of other investigators.

\section{1 construction of test rig}

A walk-in cold room is designed and has been constructed to evaluate the performance and power consumption using a vapor compression cycle with R134a and R1234ze as refrigerants. Figure 1 shows a view of the main component of the vapor compression cycle which consists of the following: $1.5 \mathrm{hp}$ reciprocating semi-ceiled compressor (K 150), lubricated by ester oil; air cold condenser with fan power $150 \mathrm{~W}$; thermostatic expansion valve (TEN2 orifice no 02) (TXV), fan coil evaporator with fan $150 \mathrm{~W}$. The evaporator is installed in a refrigerated room $(2.4 \mathrm{~m}$ length $\times 1.7 \mathrm{~m}$ width $\times 2.5$ height). The room is insulated by prefabricated polyurethane foam panel with thickness of $10 \mathrm{~cm}$ and density $\rho=40 \mathrm{~kg} / \mathrm{m}^{3}$. Inner and outer surface are covered with steel sheets with thickness of $0.5 \mathrm{~mm}$.

\subsection{Experimental test procedure}

Schematic diagram of the vapor compression cycle including the measuring points of pressure and temperature is shown in Fig.2. In the vapor compression cycle there are seven points for measuring pressure and temperature (their locations can be seen in Fig. 2).

Compressor power consumption, ambient temperature and cold room air temperatures are also measured. Table 1 summarizes the instrumentation characteristics. All of these data is gathered using a data acquisition system. Then all of data is monitored and stored through a Personal Computer 


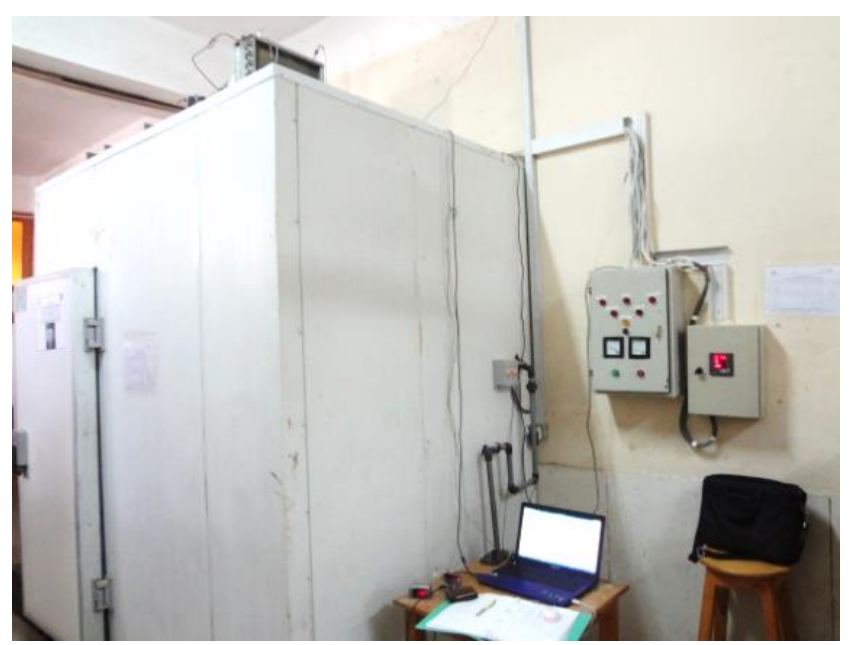

(a)

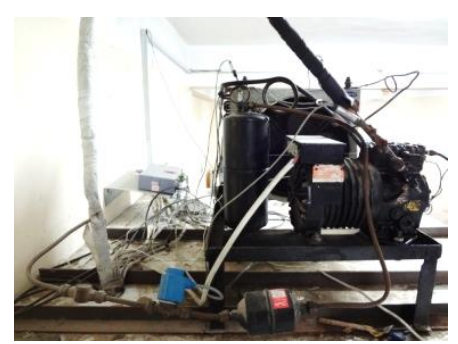

(b)

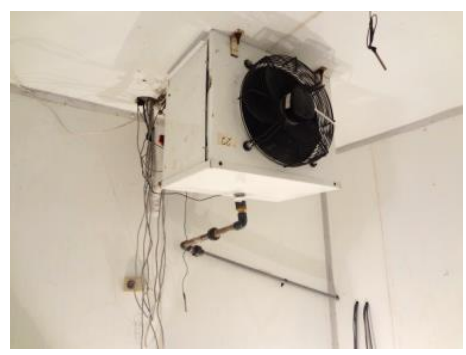

(c)

Figure 1 Photo of test rig: (a) Wall panel insulation and control panel (b) Condensing unit including all auxiliary components (c) Fan coil evaporator

Table 1: Measured parameters and equipment uncertainty

\begin{tabular}{l|l|l}
\multicolumn{1}{c|}{ Measured parameters } & \multicolumn{1}{c}{ Sensor } & Accuracy \\
\hline Air temperatures & Thermocouples type DS18B20 & $\pm 0.5 \mathrm{C}$ \\
\hline Refrigerant temperature & Thermocouples type DX NTC NS 6 & $\pm 0.1{ }^{\circ} \mathrm{C}$ \\
\hline Refrigerant pressure & Pressure transducer eliwell EWPA & $\pm 7 \mathrm{kPa}$ \\
\hline Power consumption & Power meter PM 1200 Shneider & $\pm 1 \%$ \\
\hline Air Velocity & Hot wire TSI 8340-M - GB & $\pm 0.1 \mathrm{~m} / \mathrm{s}$
\end{tabular}

\subsection{Data reduction}

In order to make complete assessment of COP for vapor compression cycle, 8 experiments are carried out (4 with each refrigerant: R1234ze and R134a), at different product loads beginning with no load and using product load simulated with steady state electric heaters with capacities 200, 400 and $600 \mathrm{~W}$. In order to calculate the refrigerant mass flow rate through the cycle, heat balance on condenser is done. Air mass flow rate through the condenser is calculated according to ASHRAE procedure. [16]

$m_{\text {air }}=v_{\text {air }} \times \rho_{\text {air }} \times A_{\text {sec }}$.

A hot wire anemometer is used to measure air velocity

$m_{\text {ref }}=\left(m_{\text {air }} c p_{\text {air }} \Delta T_{\text {air }}\right) / \Delta h_{\text {refc }}$

where $\Delta T_{\text {air }}$ is the air temperature difference through the condenser.

The cooling capacity $\mathrm{Q}_{c}$ consist of the product load plus all losses from the room (transmission load, equipment load, infiltration load, cycle losses, etc.). To calculate cooling capacity of cycle, pressure and temperature are measured at inlet of TXV and outlet of evaporator.

Total cooling capacity is calculated from Eqn. 3as,

$Q_{c .}=m_{\text {ref. }} \times \Delta h_{e}$

The superheating degree at evaporator outlet ranges at [710] ${ }^{\circ} \mathrm{C}$ and subcooling degree at condenser outlet is measured as $[2-6]^{\circ} \mathrm{C}$.

To calculate Carnot COP of the cycle, evaporator and ambient temperatures are measured.

$C O P_{c}=\frac{T_{e}}{T_{\mathrm{c}}-T_{e}}$

To calculate the actual COP of cycle, cooling capacity is calculated from Eq. (3) and power consumption is measured and COP is evaluated as;

$C O P=\frac{Q_{c . c .}}{P_{c}}$

To calculate the actual refrigeration efficiency, $\eta_{R}$, [17] of the cycle, COP and $\mathrm{COP}_{\mathrm{c}}$ are calculated and $\eta_{R}$ is evaluated as,

$\eta_{R}=\frac{C O P}{C P_{c}}$ 


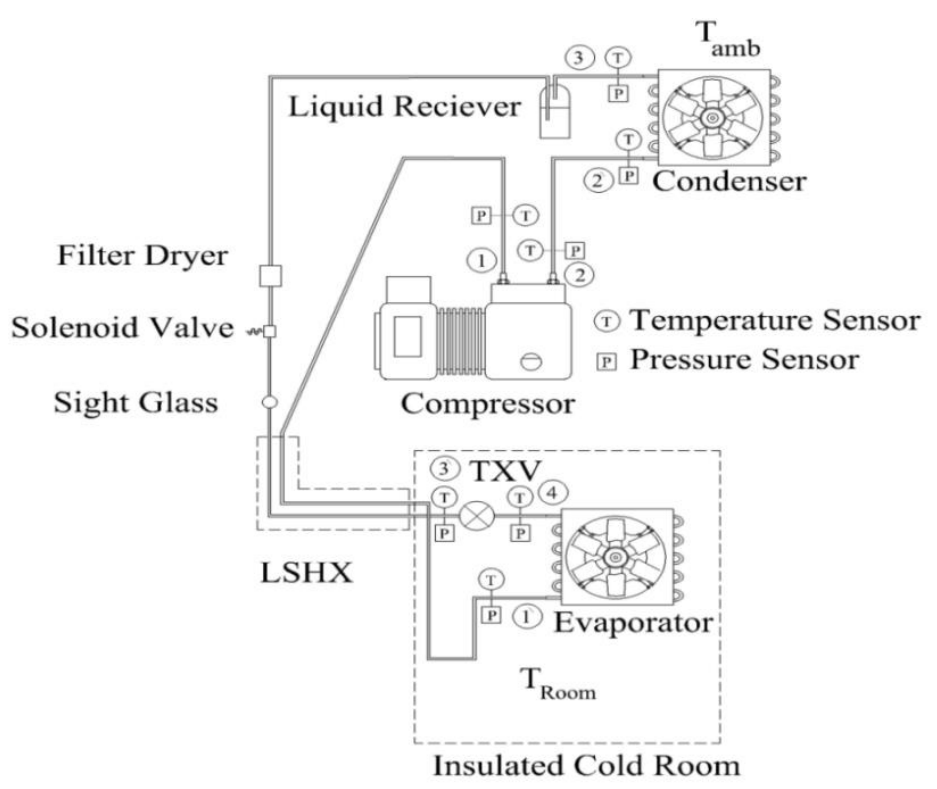

Figure 2 Schematic diagram of the test rig

\section{Results and discussions}

This section presents and discusses the experimental results obtained using R134a and R1234ze as working fluids. The parameters measured are inlet and outlet refrigerant pressures and temperatures of compressor, cold air temperatures \& outlet condenser refrigerant temperature, air velocity through condenser, power consumption and evaporator temperature. The parameters analyzed are $\mathrm{COP}, \mathrm{COP}_{\mathrm{C}}, \eta_{R}$ and cooling capacity to make complete assessment in performance comparison between the two refrigerants.

Discharge pressure for $\mathrm{R} 134 \mathrm{a}$ is almost higher than R1234ze and suction pressure for R1234ze is also lower than R134a as shown in Fig. 3. For R134a the compression ratio is higher than that for $\mathrm{R} 1234 \mathrm{ze}$.

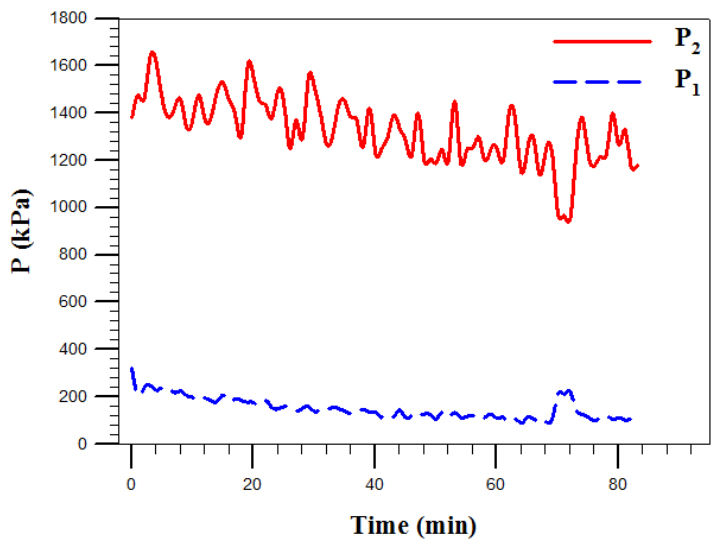

(a)
Discharge pressure for R1234ze are about 25-40 \% lower than that of R134a at same $\mathrm{T}_{\mathrm{e}}$. Also suction pressure for R1234ze is ranged between 10-49 \% less than that of $\mathrm{R} 134 \mathrm{a}$ at same $\mathrm{T}_{\mathrm{e}}$.

The average air temperature for $\mathrm{R} 134 \mathrm{a}$ records faster drop than the same case of R1234ze; as shown in Fig. 4. That difference in faster dropping of air temperature is due to the fact that both refrigerants have different thermophysical prosperities. At load $600 \mathrm{~W}$ R1234ze takes 44 min to achieve $\mathrm{T}_{\mathrm{r} \text { avg. }}=0{ }^{\circ} \mathrm{C}$ and $79 \min \mathrm{T}_{\mathrm{r} \text { avg. }}=-$ $5{ }^{\circ} \mathrm{C}$ in, while $\mathrm{R} 134 \mathrm{a}$ achieves $\mathrm{T}_{\mathrm{r} \text { avg. }}=0{ }^{\circ} \mathrm{C}$ within $35 \mathrm{~min}$ and $\mathrm{T}_{\mathrm{r} \text { avg. }}=-5^{\circ} \mathrm{C}$ in $76 \mathrm{~min}$. Temperatures of refrigerant at point 3 and 3' for R1234ze are almost lower than that for R134a as shown in Fig. 4.

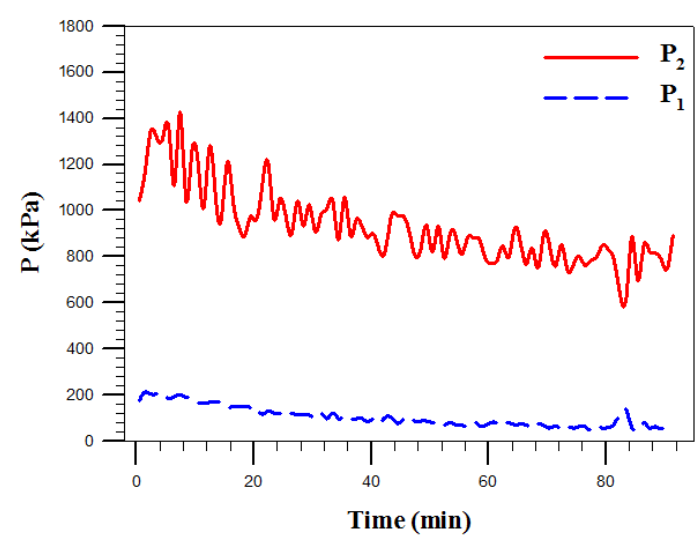

(b)

Figure 3 Compressor inlet and outlet pressures vs. time at $600 \mathrm{~W}$ load, (a) for R134a, (b) for R1234ze 


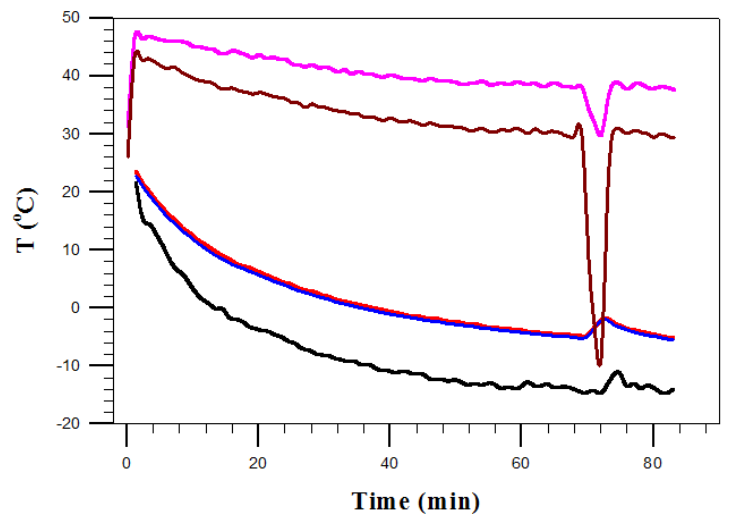

(a)

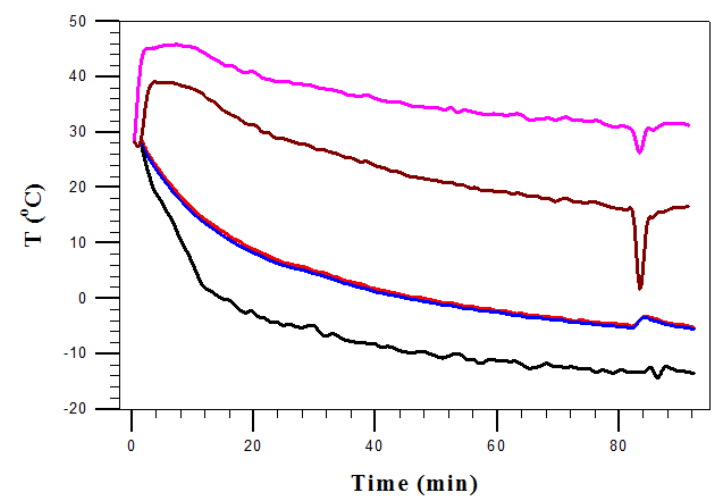

(b)

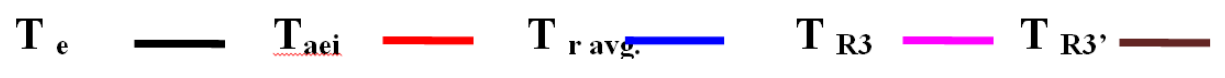

Figure $4 \mathrm{~T}_{\mathrm{e}}, \mathrm{T}_{\text {aei }}, \mathrm{T}_{\mathrm{r} \text { avg. }}, \mathrm{T}_{\mathrm{R} 3}$ and $\mathrm{T}_{\mathrm{R} 3}$, vs. time at $600 \mathrm{~W}$, (a) for $\mathrm{R} 134 \mathrm{a}$, (b) for $\mathrm{R} 1234 \mathrm{ze}$

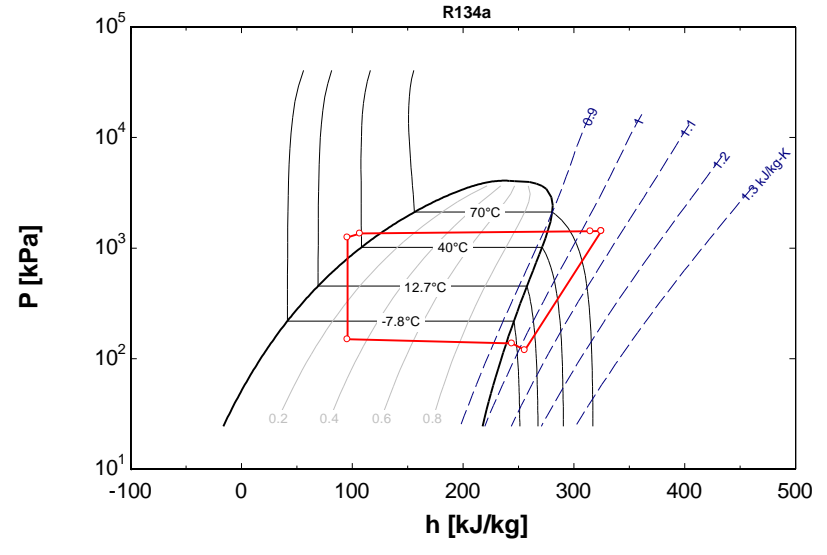

(a) At time 49 min for R134a

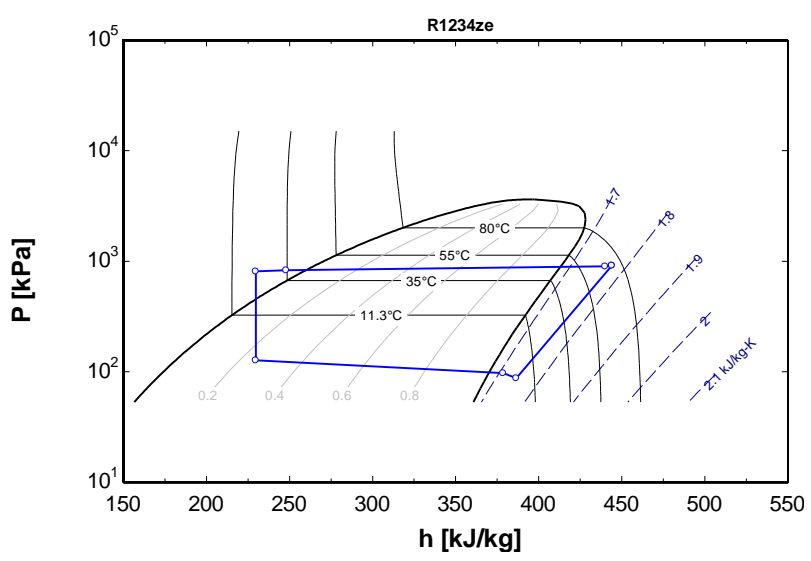

(b) At time $71 \mathrm{~min}$ for R1234ze [18]

Figure 5 P-h diagram of the two cycles at same $T_{e}=-12.6{ }^{\circ} \mathrm{C}$

Figure 5 (a) and (b) shows the P-h charts for both R134a and R1234ze, respectively at evaporator temperature $-12.6{ }^{\circ} \mathrm{C}$. From Fig. 5 (a), it is shown that for $\mathrm{R} 134 \mathrm{a}$ there is pressure drop in condenser of $64 \mathrm{kPa}$ and in evaporator of $12.7 \mathrm{kPa}$. Also there is increase in entropy in compression process of $0.031 \mathrm{~kJ} / \mathrm{kg} . \mathrm{K}$. From Fig. 5 (b), it is shown that for R1234ze there is pressure drop in condenser of $72.1 \mathrm{kPa}$ and in evaporator of 29.47 $\mathrm{kPa}$. Also there is increase in entropy in compression process of $0.028 \mathrm{~kJ} / \mathrm{kg} . \mathrm{k}$.
Cooling capacity of R134a is almost higher than that of R1234ze. As it is significant clear the $\mathrm{Q}_{c . c}$ decreases by decreasing $\mathrm{T}_{\mathrm{e}}$. For the case of no load at the same evaporator temperature about $20{ }^{\circ} \mathrm{C}$ it is recorded that $\mathrm{Q}_{\mathrm{c.c}}$ is $4.54 \mathrm{~kW}$ for $\mathrm{R} 1234 \mathrm{ze}$ and $4.56 \mathrm{~kW}$ for $\mathrm{R} 134 \mathrm{a}$ the difference in values is about $0.4 \%$ for R1234ze less than that of R134a. 


$$
\ldots * . . T_{\text {eR1234ze }} \cdots \cdots T_{\text {eR134a }} \rightarrow Q_{\text {c..R134a }} \rightarrow \mathbf{Q}_{\text {c.c.R1234ze }}
$$

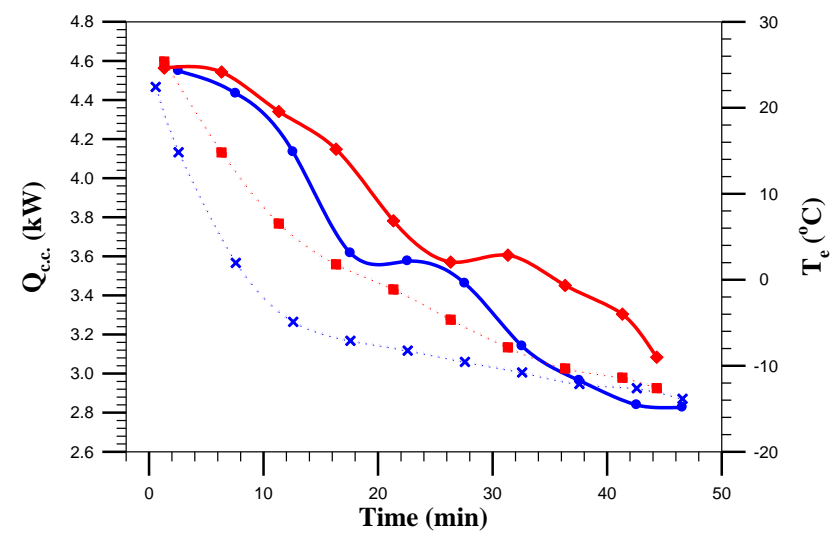

(a) at no load

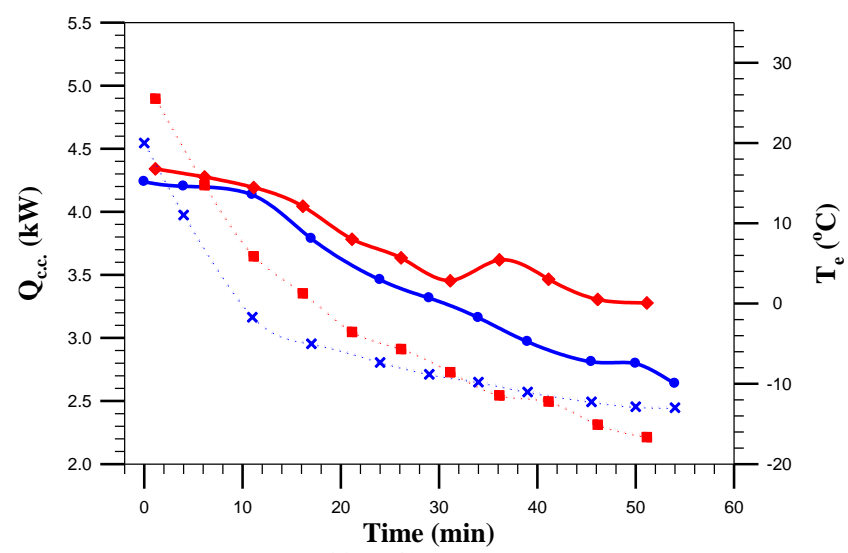

(c) at $400 \mathrm{~W}$ load

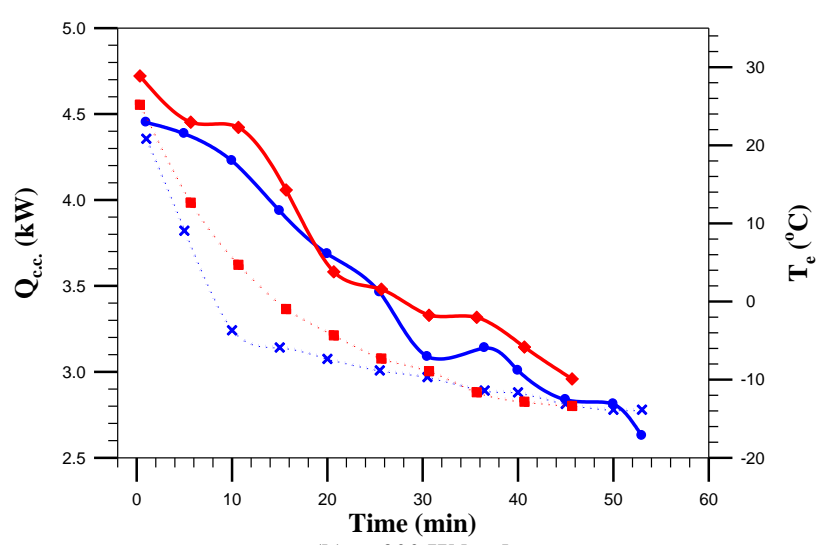

(b) at $200 \mathrm{~W}$ laod

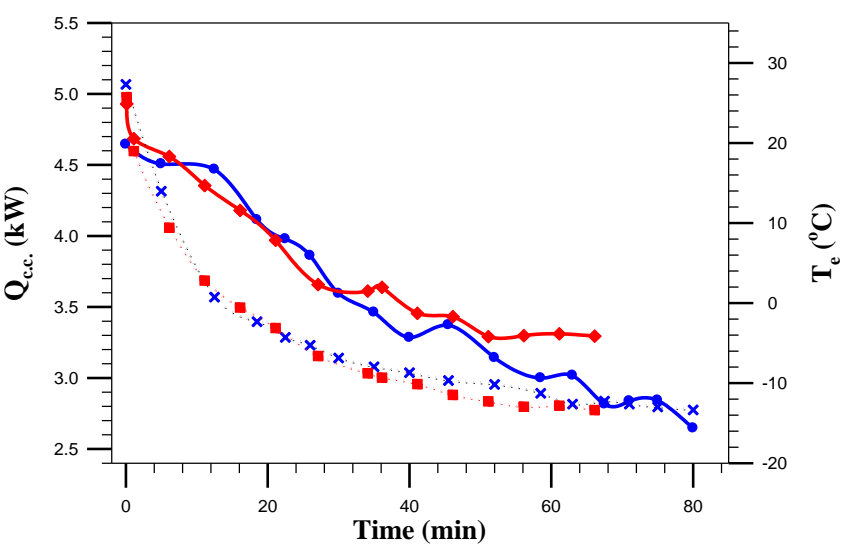

(d) at $600 \mathrm{~W}$ load

Figure $6 \mathrm{Q}_{\mathrm{c} .}$. And $\mathrm{T}_{\mathrm{e}}$ vs. time at different cases, (a), (b), (c) and (d)

For R134a it achieves $\mathrm{Te}=-13{ }^{\circ} \mathrm{C}$ faster than R1234ze with about 5 min as shown in Fig. 6 (a).For the case of $200 \mathrm{~W}$ load at the same $\mathrm{T}_{\mathrm{e}}=20{ }^{\circ} \mathrm{C}$ it is recorded that the $\mathrm{Q}_{\text {c.c }}$ is $4.54 \mathrm{~kW}$ for $\mathrm{R} 1234 \mathrm{ze}$ and $4.75 \mathrm{~kW}$ for $\mathrm{R} 134 \mathrm{a}$, it decreases by $4.4 \%$ than that for R134a. For R134a it archives $\mathrm{T}_{\mathrm{e}}=-13{ }^{\circ} \mathrm{C}$ faster than R1234ze about 8 min as shown in Fig. 6 (b).

For the case of $400 \mathrm{~W}$ load at the same $\mathrm{T}_{\mathrm{e}}=20{ }^{\circ} \mathrm{C}$ the $\mathrm{Q}_{\text {c.c }}$ is $4.25 \mathrm{~kW}$ for $\mathrm{R} 1234 \mathrm{ze}$ and $4.35 \mathrm{~kW}$ for $\mathrm{R} 134 \mathrm{a}$ with decrease of $2.3 \%$ as shown in Fig. 6 (c).

For the case of $600 \mathrm{~W}$ load at the same $\mathrm{T}_{\mathrm{e}}=21{ }^{\circ} \mathrm{C}$ the $\mathrm{Q}_{\mathrm{c} . \mathrm{c}}$ is $4.64 \mathrm{~kW}$ for R1234ze and $4.93 \mathrm{~kW}$ for $\mathrm{R} 134 \mathrm{a}$ it decreases by $5.9 \%$ as shown in Fig. 6 (d). Qc.c consists of the product load plus all loses from the room about 2.8 $\mathrm{kW}$. At the end of all testes recording that the difference in $\mathrm{Q}_{\mathrm{c} . \mathrm{c}}$ values for $\mathrm{R} 1234 \mathrm{ze}$ about $2-13 \%$ less than R134a.

COP of R1234ze is almost higher than that for R134a and the deference between them decreases by decreasing $\mathrm{T}_{\mathrm{e}}$ for all cases as shown in Fig. 7. For the case of no load at the same $\mathrm{T}_{\mathrm{e}}=14.8{ }^{\circ} \mathrm{C}$ it is recorded that the deviation about $28.5 \%$ and decreases to $12.23 \%$ at the same $\mathrm{T}_{\mathrm{e}}=-7.1^{\circ} \mathrm{C}$ as shown in Fig. 7 (a). For the case of $200 \mathrm{~W}$ load, at the same $\mathrm{T}_{\mathrm{e}}=-3.67{ }^{\circ} \mathrm{C}$ the deviation is significant high about $29.2 \%$ and decreases to $6.87 \%$ at $\mathrm{T}_{\mathrm{e}}=-13.1^{\circ} \mathrm{C}$ as shown in Fig. 7 (b).For the case of $400 \mathrm{~W}$ load as shown in Fig. 7 (c), at the same $\mathrm{T}_{\mathrm{e}}$ $=11.3{ }^{\circ} \mathrm{C}$ the deviation is about $31.9 \%$ and decreases to $4.7 \%$ at $\mathrm{T}_{\mathrm{e}}=-12{ }^{\circ} \mathrm{C}$. For the case of $600 \mathrm{~W}$ load as shown in Fig. 7 (d), at the same $\mathrm{T}_{\mathrm{e}}=13.9{ }^{\circ} \mathrm{C}$ the deviation reaches about $33 \%$ and decreases to $12.1 \%$ at $\mathrm{T}_{\mathrm{e}}=-11.2$ ${ }^{\circ} \mathrm{C}$.

Total power consumption for the system using R1234ze is lower than that for R134a. For the case of no load at starting of system $P_{c}$ for R1234ze is significant recorded about $12.25 \%$ lower than that of R134a at the same $\mathrm{T}_{\mathrm{e}}=16{ }^{\circ} \mathrm{C}$, then this difference decreased to be $9.36 \%$ at the same $\mathrm{T}_{\mathrm{e}}=-7.1{ }^{\circ} \mathrm{C}$ and then increased to be $14 \%$ at the same $\mathrm{T}_{\mathrm{e}}=-13{ }^{\circ} \mathrm{C}$ as shown in Fig. 8 (a). 


\section{$\rightarrow$ \% rfe.effi ${ }_{\text {R1234ze }} \rightarrow$ \%ref.eff. ${ }_{\text {R134a }} \rightarrow-\mathrm{COP}_{\mathrm{R} 134 \mathrm{a}} \rightarrow \mathrm{COP}_{\mathrm{R} 12342 \mathrm{e}}$}

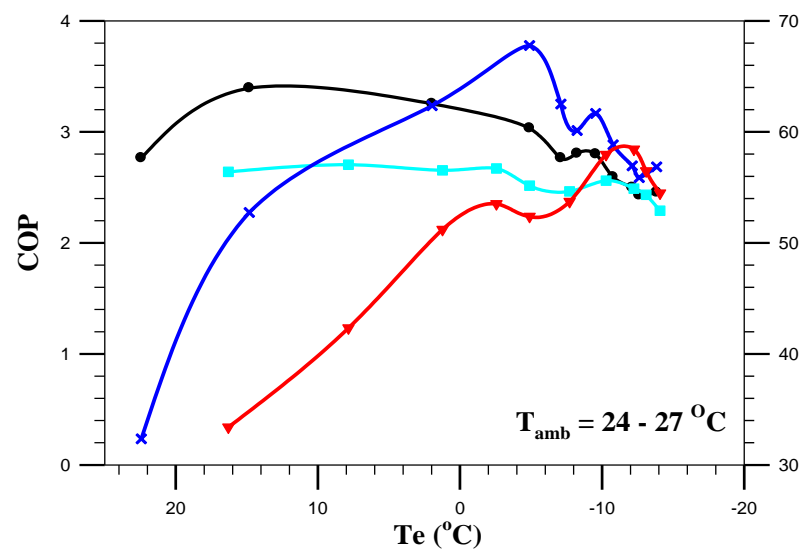

(a) at no load

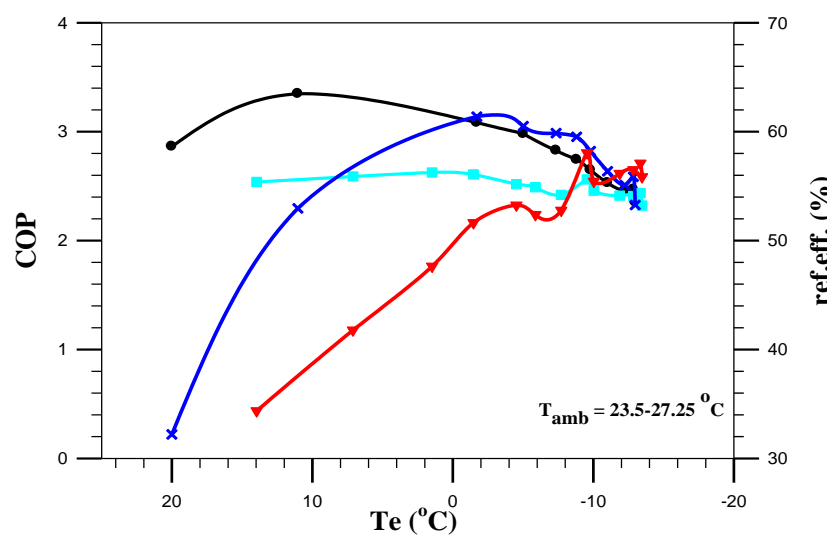

(c) at $400 \mathrm{~W}$ load

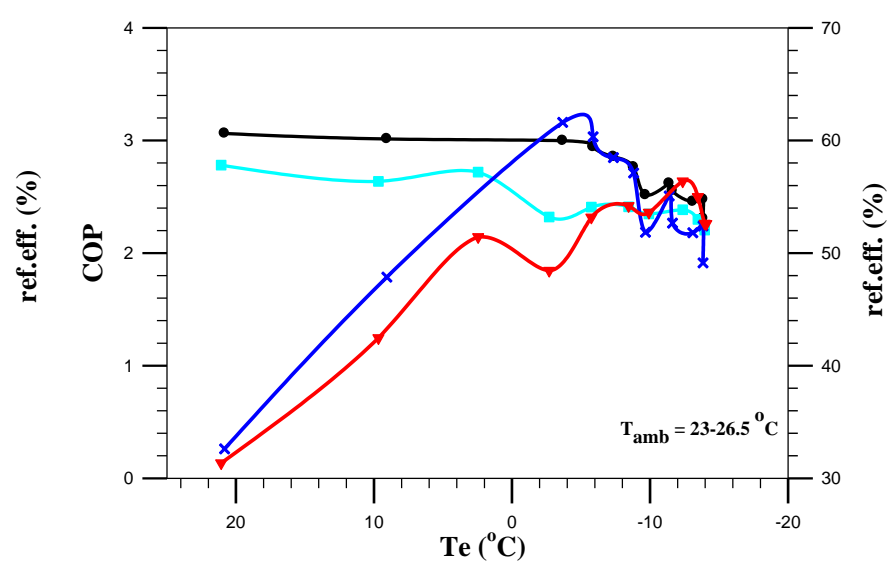

(b) at $200 \mathrm{~W}$ load

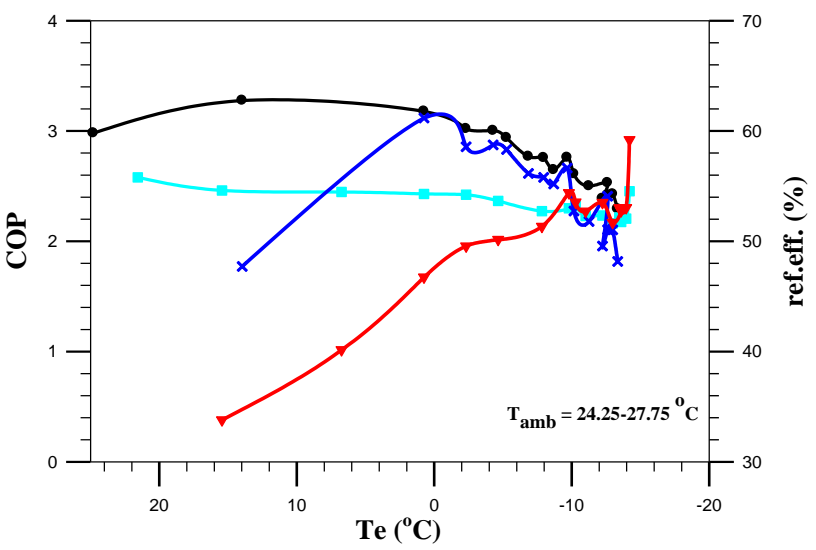

(d) at $600 \mathrm{~W}$ load

Figure $7 \mathrm{COP}$ and refrigeration efficiency vs. $\mathrm{T}_{\mathrm{e}}$ at different cases, (a), (b), (c) and (d)

For the case of $200 \mathrm{~W}$ load $\mathrm{P}_{\mathrm{c}}$ for R1234ze at the same $\mathrm{T}_{\mathrm{e}}=21{ }^{\circ} \mathrm{C}$ is lower than R134a about $14.4 \%$, and at the same $\mathrm{T}_{\mathrm{e}}=-13{ }^{\circ} \mathrm{C}$ the difference in $\mathrm{P}_{\mathrm{c}}$ for R1234ze goes to be $15.5 \%$ lower than that for R134a as shown in Fig. 8 (b).

For the case of $400 \mathrm{~W}$ load $\mathrm{P}_{\mathrm{c}}$ for R1234ze at the same $T_{e}=11{ }^{\circ} \mathrm{C}$ is significantly lower than that of R134a about $15 \%$ and it goes up to about $17.4 \%$ at the same $\mathrm{T}_{\mathrm{e}}=-13{ }^{\circ} \mathrm{C}$ as shown in Fig. 8 (c). For the case of $600 \mathrm{~W}$ load $\mathrm{P}_{\mathrm{c}}$ for $\mathrm{R} 1234 \mathrm{ze}$ at the same $\mathrm{T}_{\mathrm{e}}=14{ }^{\circ} \mathrm{C}$ is recording maximum difference on values for R1234ze about 21.3 $\%$ than R134a, then it increased at the same $\mathrm{T}_{\mathrm{e}}=-13{ }^{\circ} \mathrm{C}$ to be about $23.8 \%$ as shown in Fig. 8 (d). 


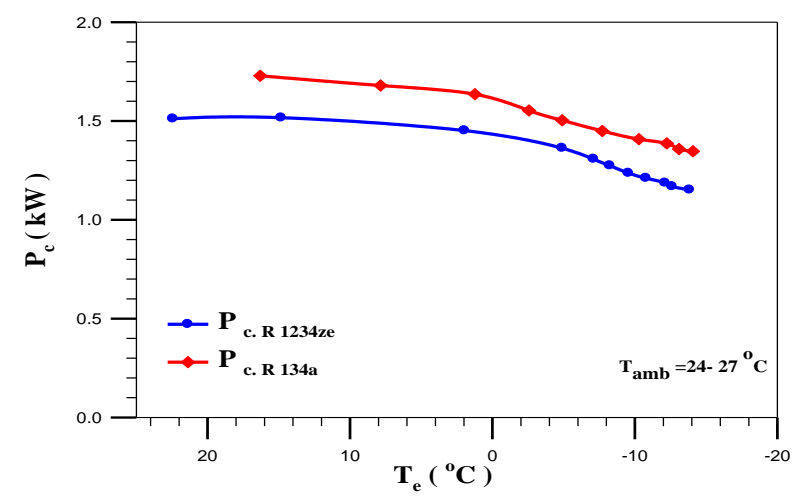

(a) at no load

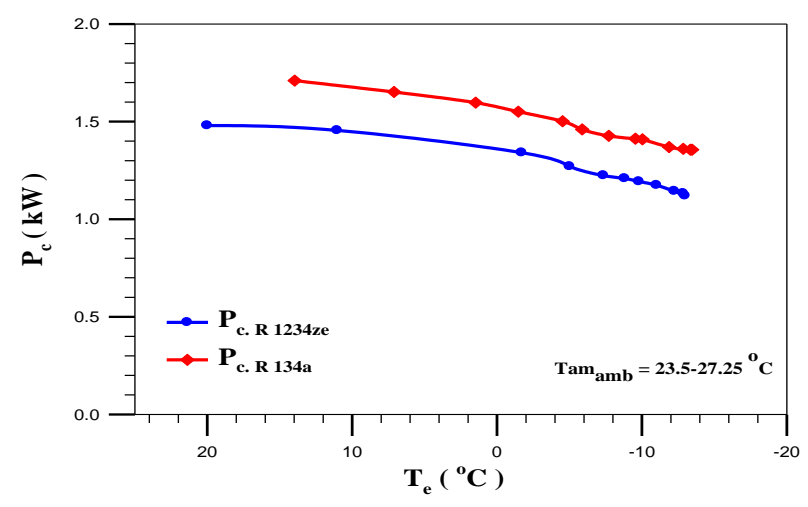

(c) at $400 \mathrm{~W}$ load

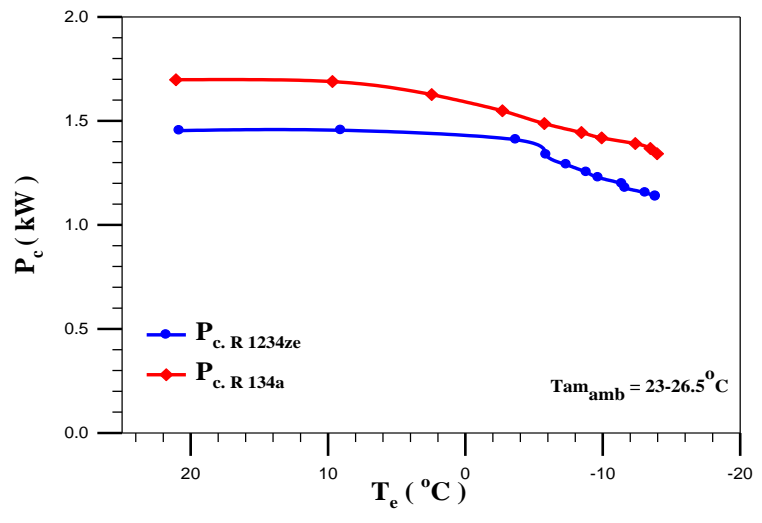

(b) at $200 \mathrm{~W}$ load

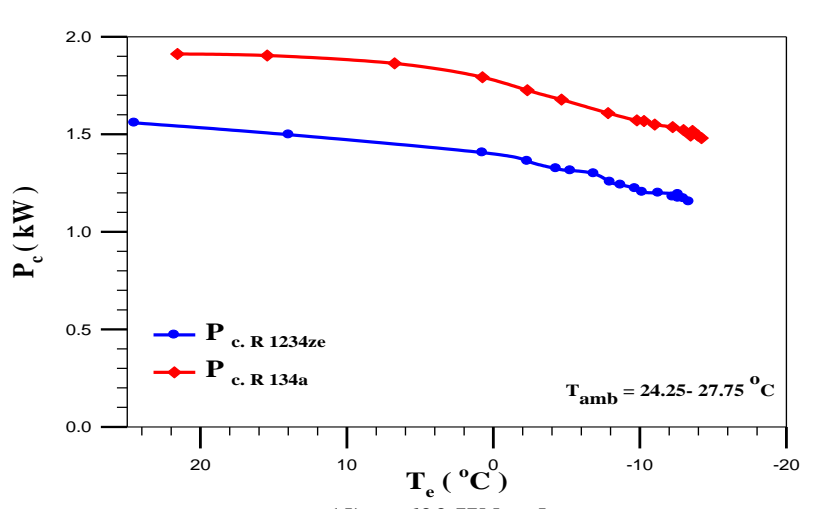

(d) at $600 \mathrm{~W}$ load

Figure $8 \mathrm{P}$ vs. $\mathrm{T}_{\mathrm{e}}$ at different cases (a), (b), (c) and (d).

\section{COMPARISON WITH OTHER EXPERIMENTAL WORK}

Table 2 shows a comparison between main variables of vapor compression cycle on our work with the work of Leighton D. et al. [9] as in the following tables:

Table 2 comparison between present work and Leighton et al. [8].

\begin{tabular}{l|l|l|l}
\multicolumn{1}{c|}{ Variable } & Leighton et al [9] & $\begin{array}{l}\text { Present work } \\
\text { R1234ze }\end{array}$ \\
\hline Compressor cooling capacity $[\mathrm{kW}]$ & 0.0962 & {$[5: 2.6]$} & Present work R134a \\
\hline Compressor discharge pressure $[\mathrm{kPa}]$ & 1095.4 & $1520: 933$ & {$[5: 2.6]$} \\
\hline Evaporator air inlet temperature $\left[{ }^{\circ} \mathrm{C}\right]$ & -10.2 & $22:-5$ & $1700: 950$ \\
\hline Condenser air inlet temperature $\left[{ }^{\circ} \mathrm{C}\right]$ & 32.8 & $30: 24$ & $32:-6$ \\
\hline Condenser volumetric air flow rate $\left[\mathrm{m}^{3} / \mathrm{s}\right]$ & 0.0283 & 0.67521 & 0.67521
\end{tabular}

Table 3 Comparison between present work at $\mathrm{Te}=-13^{\circ} \mathrm{C}$ and air inlet temperature to evaporator-5 ${ }^{\circ} \mathrm{C}$ for $\mathrm{R} 134 \mathrm{aand} \mathrm{R} 1234 \mathrm{ze}$, internal load $600 \mathrm{~W}$

\begin{tabular}{l|l|l|l|l} 
variables & $\begin{array}{l}\text { R134a } \\
\text { Present work }\end{array}$ & $\begin{array}{l}\text { R1234ze } \\
\text { Present work }\end{array}$ & $\begin{array}{l}\text { R134a } \\
\text { Leighton et al [9] }\end{array}$ \\
\hline COP & 2.175 & 2.2919 & 1.604 & 1.731 \\
\hline Compressor power $[\mathrm{kW}]$ & 1.5168 & 1.1927 & 0.1213 & 0.0882 \\
\hline Evaporator Capacity [kW] & 3.2936 & 2.6464 & 0.1945 & 0.1527 \\
\hline Mass Flow Rate $[\mathrm{kg} / \mathrm{s}]$ & 0.02083 & 0.01855 & 0.001251 & 0.00128 \\
\hline Discharge Pressure [kPa] & 1076.22 & 901.77 & 1196 & 851 \\
\hline Suction Pressure $[\mathrm{kPa}]$ & 310.65 & 163.07 & 132.6 & 102
\end{tabular}

\section{CONCLUSIONS}

In this research, a commercial vapor compression system is used to refrigerate a walk-in cold room.
Performance of the system using R1234ze is studied and compared with the same system using R134a. It is significantly recorded that R1234ze has a COP about 7 - 
$33 \%$ higher than that of R134a in all cases. It has been shown that R1234ze requires less power than R134a with about $9-15 \%$. However R1234ze has lower $\mathrm{Q}_{\text {c. }}$ than R134a of about $2-13 \%$ which can be considered comparable with R134a.

\section{NOMENCLATURE}

\begin{tabular}{|c|c|}
\hline$\Delta h_{\text {ref.e }}$ & $\begin{array}{l}\text { Refrigerant enthalpy change in the } \\
\text { evaporator } \mathrm{kJ} / \mathrm{kg}\end{array}$ \\
\hline$\Delta h_{\text {ref.c }}$ & $\begin{array}{l}\text { Refrigerant enthalpy change in the } \\
\text { condenser } \mathrm{kJ} / \mathrm{kg}\end{array}$ \\
\hline$\Delta T_{\text {air }}$ & $\begin{array}{l}\text { Air temperature difference across the } \\
\text { condenser, } \mathrm{K}\end{array}$ \\
\hline$c p_{\text {air }}$ & Air specific heat, kJ/kg.K \\
\hline$\eta_{R}$ & Refrigeration efficiency \\
\hline $\mathrm{Q}_{\mathrm{c} .}$ & Cooling capacity, $\mathrm{kW}$ \\
\hline$P_{c}$ & Power consumption, kW \\
\hline $\mathrm{T}_{\text {aei }}$ & Evaporator air inlet temperature, ${ }^{\circ} \mathrm{C}$ \\
\hline & Evaporator temperature, ${ }^{\circ} \mathrm{C}$ \\
\hline $\begin{array}{c}\mathrm{T}_{\infty}, \mathrm{T}_{\mathrm{amb}} \\
m_{R}\end{array}$ & $\begin{array}{l}\text { Ambient temperature, }{ }^{\circ} \mathrm{C} \\
\text { Refrigerant mass flow rate, } \mathrm{kg} / \mathrm{s}\end{array}$ \\
\hline $\mathrm{p}_{2}$ & Compressor outlet pressure, $\mathrm{kPa}$ \\
\hline$m_{\text {air }}$ & Air mass flow rate, $\mathrm{kg} / \mathrm{s}$ \\
\hline$v_{\text {air }}$ & Air velocity, $\mathrm{m} / \mathrm{s}$ \\
\hline $\mathrm{COP}$ & Coefficient of performance \\
\hline $\mathrm{COP}_{\mathrm{c}}$ & Carnot coefficient of performance \\
\hline & Refrigerant enthalpy, $\mathrm{kJ} / \mathrm{kg}$ \\
\hline$\rho_{\text {air }}$ & Air density, $\mathrm{kg} / \mathrm{m}^{3}$ \\
\hline$A_{\text {sec. }}$ & Air cross section of condenser, $\mathrm{m}^{2}$ \\
\hline $\mathrm{T}_{\mathrm{r} \text { avg. }}$ & Room average temperature, ${ }^{\circ} \mathrm{C}$ \\
\hline $\mathrm{T}_{\mathrm{R} 3}$ & Refrigerant temp. at condenser outlet, ${ }^{\circ} \mathrm{C}$ \\
\hline $\mathrm{T}_{\mathrm{R} 3}$, & $\begin{array}{l}\text { Refrigerant temperature at expansion } \\
\text { inlet, }{ }^{\circ} \mathrm{C}\end{array}$ \\
\hline$p_{1}$ & Compressor inlet pressure, $\mathrm{kPa}$ \\
\hline
\end{tabular}

ABBREVIATIONS

GWP Global worming potential

ODP Ozone depletion potential

TXV Thermostatic expansion valve

AHAM Association of home appliance manufacturers

HRF-1 Household Refrigerators, refrigerator Freezers and freezers

\section{REFERENCES}

[1] National Refrigerants Inc., Refrigerant Reference Guide, Fourth Edition (4.01), 2004 by NRI ${ }^{\mathrm{TM}}$.

[2] Kyoto Protocol, Report of the Conference of the Parties, United Nations Framework Convention on Climate Change (UNFCCC), 1997

[3] United Nations Environment Program (UNEP), Montreal Protocol on Substances that Deplete the Ozone Layer, Final Act, United Nations, New York, 1997.

[4] M.O. McLinden, A.F. Kazakov, J.S. Brown, P.A. Domanski, A thermodynamic analysis of refrigerants: possibilities and tradeoffs for lowGWP refrigerants, International Journal of Refrigeration 38 (2013) 80 - 92.
[5] World Meteorological Organization (WMO), Scientific Assessment of Ozone Depletion: 2006, Global Ozone, Research and Monitoring Project Report 50, Geneva, Switzerland, 2007.

[6] Nielsen O.J., M.S. Javadi, A. Sulbak, M.D. Hurley, T.J. Wallington, R. Singh, Atmospheric chemistry of $\mathrm{CF} 3 \mathrm{CF}=\mathrm{CH} 2$ : Kinetics and mechanisms of gas-phase reactions with $\mathrm{Cl}$ atoms, $\mathrm{OH}$ radicals, and O3. Chemical Physics Letters 439 (2007), 18 - 22.

[7] Papadimitriou V.C., R.K. Talukdar, R.W. Portmann, A.R. Ravishankara, J.B. Burkholder, $\mathrm{CF} 3 \mathrm{CF}=\mathrm{CH} 2$ and $(\mathrm{Z})-\mathrm{CF} 3 \mathrm{CF}=\mathrm{CHF}$ : Temperature dependent $\mathrm{OH}$ rate coefficients and global warming potentials, Physical Chemistry and Chemical Physics 10 (2008), 808 - 820.

[8] Koban M., HFO-1234yf Low GWP Refrigerant LCCP Analysis, SAE Technical Paper 2009-010179, doi: 10.4271/2009-01-0179.

[9] Leighton D., Y. Hwang, R. Radermacher, Modeling of household refrigerator performance with low global warming potential alternative refrigerants, ASHRAE Transactions 118 (2012), $658-665$.

[10] Francisco Molés, Joaquín Navarro-Esbr, Bernardo Peris, Adrián Mota-Babiloni, ÁngelBarragánCervera, Theoretical energy performance evaluation of different single stage vapour compression refrigeration configurations using R1234yf and R1234ze(E) as working fluids, International Journal of Refrigeration 44, 141-150, (2014).

[11] Giulia Righetti, Claudio Zilio, Giovanni A. Longo, Comparative performance analysis of the low GWP refrigerants HFO1234yf, HFO1234ze(E) and HC600a inside a roll-bond evaporator, international journal of refrigeration 54, I-9, (2015).

[12] Adrian Mota-Babiloni, Joaquín Navarro-Esbrí, Angel Barragan Cervera, Francisco Moles, Bernardo Peris, Drop-in analysis of an internal heat exchanger in a vapour compression system using R1234ze(E) and R450A as alternatives for R134a, Energy accepted on line 2015.06

[13] Kazushige Kasai, Phillip Johnson, System Drop-in Test of R134a Alternative Fluids R-1234ze(E) and D4Y in a 200 RT Air-Cooled Screw Chiller AirConditioning, Heating, and Refrigeration Institute (AHRI) Low-GWP Alternative Refrigerants Evaluation Program (Low-GWP AREP) August 20, 2013

[14] AHAM. (2008). AHAM HRF-1-2008. Energy and Internal Volumes of Refrigerating Appliances. Washington, DC.

[15] Kyle Melvin Karber, Omar Abdelaziz, Edward A. Vineyard, Experimental Performance of R-1234yf and R-1234ze as Drop-in Replacements for R134a in Domestic Refrigerators, International Refrigeration and Air Conditioning Conference at Purdue, July 16-19, 2012. 
M: 40 A. KHALIL, A.E. KABEEL, M.M. BASSUONI \& M.S.RASLAN

[16] ASHRAE Handbook 2005 Fundamentals page 14.18

[17] ASHRAE Fundamentals Handbook 2001 Fundamentals page 1.3.

[18] Ryo Akasaka, An application of the extended corresponding states model to thermodynamic property calculations for trans-1,3,3,3tetrafluoropropene (HFO-1234ze(E)) international journal of refrigeration 33, (2010), 907-914. 